\title{
Lactofen and kinetin in soybean yield ${ }^{1}$
}

\author{
Inara Alves Martins ${ }^{2}$, Silvino Guimarães Moreira², \\ Adriano Teodoro Bruzi², Guilherme Vieira Pimentel ${ }^{2}$, Paulo Eduardo Ribeiro Marchiori ${ }^{2}$
}

ABSTRACT

The herbicide lactofen has been used by producers in many conditions, in order to increase the soybean yield. This study aimed to evaluate the influence of lactofen and the phytohormone kinetin on the morpho-agronomic traits, carbohydrate partitioning and yield, in soybean cultivars. Three experiments were carried out in the field, in addition to one experiment in a greenhouse. A randomized block design, with four replications, was used. The treatments were: lactofen [144 $\mathrm{g} \mathrm{ha}^{-1}$ of active ingredient (a.i.)], lactofen + kinetin $\left(144 \mathrm{~g} \mathrm{ha}^{-1}\right.$ of a.i. $\left.+0.5 \mathrm{~g} \mathrm{ha}^{-1}\right)$, kinetin $\left(0.5 \mathrm{~g} \mathrm{ha}^{-1}\right)$, manual cutting of apical buds and control. In the subplots, six soybean cultivars (M 6410 IPRO, M 5917 IPRO, NS 7670 RR, NS 6909 IPRO, BMX Lança IPRO and Produza IPRO) were used. In the field, the plant lodging index, plant height, number of nodes and branches, pods and grains per plant, mass of 100 grains and grain yield were evaluated. In the greenhouse, the starch, reducing sugars, sucrose and total sugars in the leaves, stems and roots of three soybean cultivars were quantified. The application of lactofen in the V6 stage influenced the morpho-agronomic traits of the cultivars in the field and increased the soybean yield by $312 \mathrm{~kg} \mathrm{ha}^{-1}$, considering all the cultivars. The phytohormone did not influence the morpho-agronomic traits neither the grain yield. The treatments did not induce modification in the partitioning of carbohydrates destined to the roots.

KEYWORDS: Glycine $\max (\mathrm{L}$.$) Merrill, PROTOX inhibitors,$ phytohormone, carbohydrates.

\section{INTRODUCTION}

Aiming at increasing the soybean yield in Brazil, new crop management techniques have been constantly adopted by producers, despite the lack of scientific support that proves the efficiency of such tools. Among these new crop management proposals, the attempt to break the apical dominance of soybean with the use of growth regulators and some herbicides that play this role indirectly, such

\section{RESUMO}

\section{Lactofen e cinetina na produtividade de soja}

O herbicida lactofen vem sendo utilizado por produtores nas mais diversas condições, visando aumentar a produtividade da soja. Objetivou-se estudar a influência de lactofen e do fitohormônio cinetina nos caracteres morfoagronômicos, partição de carboidratos e produtividade, em cultivares de soja. Foram conduzidos três experimentos em campo, além de um experimento em casa-de-vegetação. Utilizou-se delineamento em blocos casualizados, com quatro repetições. Os tratamentos foram: lactofen [144 $\mathrm{g} \mathrm{ha}^{-1}$ de ingrediente ativo (i.a.)], lactofen + cinetina (144 $\mathrm{g} \mathrm{ha}^{-1}$ de i.a. $\left.+0,5 \mathrm{~g} \mathrm{ha}^{-1}\right)$, cinetina $\left(0,5 \mathrm{~g} \mathrm{ha}^{-1}\right)$, corte manual das gemas apicais e controle. Na subparcela, foram utilizadas seis cultivares de soja (M 6410 IPRO, M 5917 IPRO, NS 7670 RR, NS 6909 IPRO, BMX Lança IPRO e Produza IPRO). Em campo, foram avaliados o índice de acamamento, altura de plantas, número de nós e ramos, vagens e grãos por planta, massa de 100 grãos e produtividade. Em casa-de-vegetação, foram quantificados o amido, açúcares redutores, sacarose e açúcares totais nas folhas, caules e raízes de três cultivares de soja. A aplicação de lactofen em V6 influenciou nas características morfoagronômicas das cultivares no campo e incrementou a produtividade em $312 \mathrm{~kg} \mathrm{ha}^{-1}$ de soja, considerando-se todas as cultivares. $\mathrm{O}$ fito-hormônio não influenciou nas características morfoagronômicas e produtividade. Os tratamentos não induziram alteração na partição de carboidratos destinados às raízes.

PALAVRAS-CHAVE: Glycine $\max (\mathrm{L}$.) Merrill, inibidores de PROTOX, fito-hormônio, carboidratos.

as lactofen, is highlighted. This contact herbicide, applied to control broadleaf weeds and selective for soybean cropping, has as its mode of action the inhibition of the enzyme PROTOX, related to the production of chlorophyll. When in contact with the soybean leaf area, it causes a phytotoxicity related to the accumulation of photodynamic compounds, compromising the leaves and the apical meristem, leading the plant to modify its concentrations of auxin and cytokinin (Duke et al. 1991, Souza et al. 2013).

${ }^{1}$ Received: Aug. 10, 2020. Accepted: Oct. 23, 2020. Published: Dec. 02, 2020. DOI: 10.1590/1983-40632020v5064906. ${ }^{2}$ Universidade Federal de Lavras, Departamento de Agricultura, Lavras, MG, Brasil.E-mail/ORCID: inaraalves.ia@gmail.com/ 0000-0001-7997-5633, silvino.moreiraufla@gmail.com/0000-0001-7840-250X, adrianobruzi@dag.ufla.br/0000-0001-6909-5157, guilherme.pimentel@ufla.br/0000-0001-9849-6427, paulo.marchiori@ufla.br/0000-0001-9767-9336. 
Auxin is one of the hormones related to the apical dominance of the plant, and direct damage in this region breaks the apical dominance. Thus, an increase in the synthesis/concentration of cytokinin (one of the hormones involved in the emission of lateral branches in the plant) may occur, as a result of the sprouting of the lateral buds present in the nodes (Müller \& Leyser 2011, Soares 2014, Gallon et al. 2016).

The apical dominance break may alter the plant architecture, reduce the height by approximately $5 \mathrm{~cm}$ and, consequently, the lodging in cultivars with a higher size (Souza et al. 2013), also modifying some production components, such as number of branches, pods and grains per plant (Rosa 2018). Many producers, because they trust in the positive effects of lactofen, use the herbicide in $100 \%$ of their crops, even without scientific proof that the product is effective for any cultivar, regardless of the dose or application time.

The application of different concentrations of lactofen [96, 192, 288 and $384 \mathrm{~g} \mathrm{ha}^{1}$ of active ingredient (a.i.)] on soybean plants of the cultivar UFV-10 caused temporary symptoms of necrosis and chlorosis, but did not affect the grain yield (Espinosa et al. 1995). Gallon et al. (2016) observed that the application of lactofen (144 $\mathrm{g} \mathrm{ha}^{-1}$ of a.i.) on the soybean cultivar CD 214 RR increased the grain yield by $5 \%$, when compared to the control treatment.

Due to this scenario, where divergences exist, it is evident the need to develop studies related to the use of lactofen, seeking to scientifically prove its effectiveness, especially if this is a profitable practice for the producer. Thus, the hypothesis of this study is that the herbicide lactofen, a PROTOX inhibitor, reduces the apical dominance and, consequently, modifies the production components and increases the soybean yield.
Plant yield is influenced by morphological and physiological characteristics of the photosynthetic and reserve organs (Smith et al. 2018). Alterations induced by herbicides that indirectly alter the photosynthetic process may modify the plant metabolism, including changes in carbohydrate pathways (Vitorino \& Martins 2012). This effect was observed by Shekoofa \& Emam (2008), with growth reducers of chlormequate and etefom, in which there was a reduction in the height of wheat plants, with a respective increase in grain yield. According to the authors, this effect was attributed to changes in the carbohydrate partition, being redirected to the ears and causing an increase in yield.

Thus, this study aimed to evaluate the influence of the use of lactofen and the phytohormone kinetin on morpho-agronomic traits, grain yield and carbohydrate partitioning, in soybean cultivars from different groups of relative maturity.

\section{MATERIAL AND METHODS}

Field experiments were carried out during the 2017/2018 crop season, in three sites of the Minas Gerais state, Brazil: Fazenda Muquém, in Lavras; Fazenda 3W, in Itutinga; and Rehagro Pesquisa, in Nazareno. In all the three locations, the soils were classified as Red Yellow Dystrophic Latosol (Embrapa 2013). According to Moraes (2019), the soils in this region have a clayey texture, with an average of $24 \%$ of sand, $25 \%$ of silt and $50 \%$ of clay. The soil chemical characterization in each location, at a depth of 0-20 cm, was carried out according to Silva (2009) (Table 1).

The field experiments were arranged in a randomized block design, in a split-plot scheme, with four replications. The experimental units consisted

Table 1. Soil chemical attributes (0-20 cm layer) for each area.

\begin{tabular}{|c|c|c|c|c|c|c|c|c|c|c|}
\hline Locations & $\begin{array}{c}\mathrm{pH} \\
\mathrm{H}_{2} \mathrm{O}\end{array}$ & $\begin{array}{c}\mathrm{OM} \\
\text { dag kg-1 }\end{array}$ & \multicolumn{4}{|c|}{$\mathrm{mg} \mathrm{dm}^{-3}$} & \multicolumn{3}{|c|}{$\mathrm{cmol}_{\mathrm{c}} \mathrm{dm}^{-3}$} & SB \\
\hline Lavras & 6.1 & 2.2 & $14.9^{(1)}$ & 5.5 & 106.0 & 3.6 & 0.7 & 0.0 & 2.7 & 4.6 \\
\hline Nazareno & 5.7 & 3.3 & $27.3^{(1)}$ & 8.9 & 87.7 & 2.4 & 0.6 & 0.0 & 3.2 & 3.2 \\
\hline Itutinga & 6.3 & 1.4 & $3.8^{(2)}$ & 6.3 & 78.2 & 2.6 & 0.6 & 0.0 & 1.2 & 3.4 \\
\hline Locations & $\begin{array}{c}\mathrm{t} \\
-\mathrm{cn} \\
\end{array}$ & $\begin{array}{r}\mathrm{T} \\
\operatorname{lm}^{-3} \\
\end{array}$ & $\mathrm{~V}$ & $\mathrm{~m}$ & $\begin{array}{l}\text { P-rem } \\
\mathrm{mg} \mathrm{L}^{-1}\end{array}$ & $\mathrm{Zn}$ & $\mathrm{Fe}$ & $\begin{array}{r}\mathrm{Mn} \\
\mathrm{mg} \mathrm{dn}\end{array}$ & $\mathrm{Cu}$ & $\mathrm{B}$ \\
\hline Lavras & 4.6 & 7.3 & 63 & 0 & - & 3.8 & 65.2 & 9.4 & 0.9 & 0.1 \\
\hline Nazareno & 3.3 & 6.5 & 51 & 0 & - & 0.6 & 67.3 & 1.8 & 0.3 & 0.3 \\
\hline Itutinga & 3.3 & 4.6 & 72 & 0 & - & 0.9 & 35.7 & 5.5 & 1.2 & 0.1 \\
\hline
\end{tabular}

(1) $\mathrm{P}$ resin; (2) $\mathrm{P}$ Mehlich-1. 
of four rows with $6.0 \mathrm{~m}, 0.6 \mathrm{~m}$ between rows and a total area of $14.4 \mathrm{~m}^{2}$. The two central rows of each plot were the useful rows, corresponding to $4.8 \mathrm{~m}^{2}$.

The main plots were the treatments lactofen (144 $\mathrm{g} \mathrm{ha}^{-1}$ of a.i.), lactofen + kinetin (144 $\mathrm{g} \mathrm{ha}^{-1}$ of a.i. $\left.+0.5 \mathrm{~g} \mathrm{ha}^{-1}\right)$, kinetin $\left(0.5 \mathrm{~g} \mathrm{ha}^{-1}\right)$ and manual cutting of the apical buds, besides the control. The subplots consisted of six soybean cultivars widely used in the region (M 6410 IPRO, M 5917 IPRO, NS 7670 RR, NS 6909 IPRO, BMX Lança IPRO and Produza IPRO). The sowing dates were November 6, 2017, November 17, 2017 and November 25, 2017, respectively for Itutinga, Nazareno and Lavras.

The treatments were sprayed using a motorized backpack sprayer. The volume of the spray solution was $200 \mathrm{~L} \mathrm{ha}^{-1}$. All the treatments were sprayed in post-emergence, when the soybean plants were in the V6 growth stage (Fehr \& Caviness 1977). The removal of the apical meristem was manually operated using scissors, with the cut made $5 \mathrm{~cm}$ below the apical meristem.

The fertilizations were carried out based on the soil chemical analysis and recommendations for high crop yield, above $3,600 \mathrm{~kg} \mathrm{ha}^{-1}$ (Sousa \& Lobato 1996). Therefore, $350 \mathrm{~kg} \mathrm{ha}^{-1}$ of the formulation NPK 02-30-20 as a starter fertilizer were applied in-furrow, in Lavras. In Nazareno, $230 \mathrm{~kg} \mathrm{ha}^{-1}$ of MAP Gold Humics were applied in-furrow and $150 \mathrm{~kg} \mathrm{ha}^{-1}$ of $\mathrm{KCl}$ as topdressing. In Itutinga, $200 \mathrm{~kg} \mathrm{ha}^{-1}$ of MAP were applied in-furrow and $250 \mathrm{~kg} \mathrm{ha}^{-1}$ of $\mathrm{KCl}$ as topdressing. The pest and disease management was carried out whenever required.

At the R8 stage (physiological maturity), five soybean plants were randomly collected in each plot, in which the plant height was measured and the number of nodes, branches, pods and grains per plant were counted. The grain yield was estimated from the harvest of the two central rows of the plots $(4.0 \mathrm{~m}$ long). After harvesting, the plants were threshed using a threshing machine. Subsequently, the grains from each plot were separated for weighing and moisture determination. After obtaining the moisture content of each sample, the moisture of the total grain mass per plot was adjusted to $13 \%$. The mass of 100 grains was measured at the time of weighing, collecting a sample of 100 grains and adjusting the moisture content to $13 \%$.

On the harvest day, the plant lodging index was also evaluated, according to a scale of 1 (all plants erect) to 5 (all plants lodged) (Bernard et al. 1965).
In order to check if breaking the apical dominance interferes with the source-drain relationships, a trial was carried out in a greenhouse, in which the quantification and partitioning of carbohydrates (sucrose, reducing sugars, total soluble sugars and starch) were analyzed in the plants. The design was randomized blocks, in a split-plot arrangement, with four replications. The main plots corresponded to the treatments lactofen $\left(144 \mathrm{~g} \mathrm{ha}^{-1}\right.$ of a.i.), lactofen + kinetin (144 and $0.5 \mathrm{~g} \mathrm{ha}^{-1}$ ), kinetin $\left(0.5 \mathrm{~g} \mathrm{ha}^{-1}\right)$ and manual cutting of the apical buds, besides the control. The subplots corresponded to three cultivars (M 5917 IPRO, NS 7670 RR and BMX Lança IPRO) chosen due to their different cycles. Therefore, M 5917 IPRO and BMX Lança IPRO are early materials for the region, in relation to the NS $7670 \mathrm{RR}$, which was the most productive material after the application of the treatments in the field.

The experiment was conducted in 5-L pots, with two plants per pot. The treatments were applied using a backpack sprayer. All treatments were applied in post-emergence, when the plants were in the V6 growth stage.

Samples were collected at 15 days after the application of the products, when the plants were in the R1 stage (beginning of blooming). Soon after the collection, the fully developed mature leaves, stems and roots of the materials were separated, to quantify the carbohydrates for each fraction of the plant.

For the quantification of total soluble sugars, sucrose, reducing sugars and starch, the extraction was performed according to Zanandrea et al. (2010). For the quantification of total soluble sugars, starch and sucrose, the Antrona method described by Yemm \& Willis (1954) was used. The quantification of reducing sugars was done by the dinitrosalicylic acid method described by Miller (1959).

For the statistical analysis, individual variance analyzes were initially performed by the $\mathrm{F}$ test for all the experiments. For the field experiments, a joint analysis was carried out involving the three sites. Subsequently, the means of both experiments were submitted to the Scott-Knott test, at $5 \%$ of probability, using the Sisvar statistical software (Ferreira 2011).

\section{RESULTS AND DISCUSSION}

In the field experiments, the plants showed the highest lodging rates in Nazareno and Itutinga, if 
compared to Lavras (Table 2). In Lavras, regardless of the cultivars, the plants remained erect, obtaining a minimum score for this parameter. Considering an average of all the cultivars and treatments, the plants grown in Itutinga and Nazareno showed a greater height, statistically, than the ones grown in Lavras. The heights were 99, 87 and $62 \mathrm{~cm}$, respectively in Itutinga, Nazareno and Lavras, what may have contributed to a higher lodging index in Nazareno and Itutinga (Souza et al. 2013, Gallon et al. 2016).

The reduction in the size of the plants in Lavras may have occurred due to the late sowing, when compared to the other locations. The sowing day in Lavras was November 25, 2017, which is already considered a late implementation period for the region. As a result, the plants would already be subjected to short days during the flowering induction stage, consequently presenting a shorter cycle and reduced plant height, once soybean is a short-day plant.

In Nazareno, NS 7670 RR and Produza IPRO showed, in general, the highest lodging rates (Table 2), when compared to the others. In Itutinga, Produza IPRO was the one that presented the highest lodging index, for most treatments. These higher predispositions to lodging of the cultivars Produza
IPRO and NS 7670 RR may be related to the factor plant height. All this because, on average, these cultivars presented a greater height (Table 3 ), in addition to a longer cycle, with a longer vegetative period.

Although Gallon et al. (2016) found a reduction for plant lodging in the cultivar CD 214 $\mathrm{RR}$, due to the application of lactofen $\left(144 \mathrm{~g} \mathrm{ha}^{-1}\right)$, in comparison to the control, in the current study there was no clear effect of the treatments. Only Produza IPRO and NS 7670 RR, cultivated in Itutinga and Nazareno, respectively, showed a decrease in plant lodging due to the application of lactofen or lactofen + kinetin. Also, Heiffig et al. (2006) did not observe a decrease in the lodging of plants, after herbicide applications at a dose of $240 \mathrm{~g} \mathrm{ha}^{-1}$ in V5. Possibly, one of the main reasons for this fact is because there was no reduction in the height of soybean plants submitted to the application of lactofen. Only in the average of all cultivars and locations the plant height decreased due to the treatments, when compared to the control.

By cutting the apical buds, the plant height of all cultivars was reduced, when compared to the control (Table 3), what was already expected, once the plants had their stem cut off when they had six nodes on the

Table 2. Plant lodging rate according to cultivars, treatments and environments.

\begin{tabular}{|c|c|c|c|c|c|}
\hline Cultivars/treatments & Control & Lactofen + kinetin & Kinetin & Cutting & Lactofen \\
\hline & \multicolumn{5}{|c|}{ Nazareno } \\
\hline M 5917 IPRO & $1.0 \mathrm{Ab} a^{*}$ & $1.0 \mathrm{Ab} a$ & $1.0 \mathrm{Ab} a$ & $1.0 \mathrm{Ab} a$ & $1.0 \mathrm{Ab} a$ \\
\hline BMX Lança IPRO & $1.0 \mathrm{Ab} a$ & $1.0 \mathrm{Ab} a$ & $1.0 \mathrm{Ab} a$ & $1.0 \mathrm{Ab} a$ & $1.0 \mathrm{Ab} a$ \\
\hline NS 6909 IPRO & $1.3 \mathrm{Ab} a$ & $1.0 \mathrm{Ab} a$ & $1.4 \mathrm{Ab} a$ & $1.1 \mathrm{Ab} a$ & $1.0 \mathrm{Ab} a$ \\
\hline NS 7670 RR & $2.6 \mathrm{Aa} b$ & $1.8 \mathrm{Bb} b$ & $2.5 \mathrm{Aa} b$ & $2.9 \mathrm{Aa} b$ & $2.1 \mathrm{Ba} b$ \\
\hline Produza IPRO & $3.0 \mathrm{Aa} b$ & $2.8 \mathrm{Aa} c$ & $2.8 \mathrm{Aa} b$ & $2.5 \mathrm{Aa} b$ & $2.5 \mathrm{Aa} b$ \\
\hline \multirow[t]{2}{*}{ M 6410 IPRO } & $1.5 \mathrm{Ab} a$ & $1.0 \mathrm{Ab} a$ & $1.8 \mathrm{Ab} a$ & $1.5 \mathrm{Ab} b$ & $1.3 \mathrm{Ab} a$ \\
\hline & \multicolumn{5}{|c|}{ Lavras } \\
\hline M 5917 IPRO & $1.0 \mathrm{Aa} a$ & $1.0 \mathrm{Aa} a$ & 1.0 Aa $a$ & $1.0 \mathrm{Aa} a$ & 1.0 Aa $a$ \\
\hline BMX Lança IPRO & $1.0 \mathrm{Aa} a$ & $1.0 \mathrm{Aa} a$ & $1.0 \mathrm{Aa} a$ & $1.0 \mathrm{Aa} a$ & 1.0 Aa $a$ \\
\hline NS 6909 IPRO & $1.0 \mathrm{Aa} a$ & $1.0 \mathrm{Aa} a$ & $1.0 \mathrm{Aa} a$ & $1.0 \mathrm{Aa} a$ & $1.0 \mathrm{Aa} a$ \\
\hline NS 7670 RR & $1.0 \mathrm{Aa} a$ & $1.0 \mathrm{Aa} a$ & $1.0 \mathrm{Aa} a$ & $1.0 \mathrm{Aa} a$ & $1.0 \mathrm{Aa} a$ \\
\hline Produza IPRO & $1.0 \mathrm{Aa} a$ & $1.0 \mathrm{Aa} a$ & $1.0 \mathrm{Aa} a$ & $1.0 \mathrm{Aa} a$ & $1.0 \mathrm{Aa} a$ \\
\hline \multirow[t]{2}{*}{ M 6410 IPRO } & $1.0 \mathrm{Aa} a$ & 1.0 Аа $a$ & $1.0 \mathrm{Aa} a$ & $1.0 \mathrm{Aa} a$ & $1.0 \mathrm{Aa} a$ \\
\hline & \multicolumn{5}{|c|}{ Itutinga } \\
\hline M 5917 IPRO & $1.0 \mathrm{Ac} a$ & $1.0 \mathrm{Ab} a$ & $1.0 \mathrm{Ab} a$ & $1.3 \mathrm{Ac} a$ & $1.0 \mathrm{Ab} a$ \\
\hline BMX Lança IPRO & $1.0 \mathrm{Ac} a$ & $1.0 \mathrm{Ab} a$ & $1.3 \mathrm{Ab} a$ & $1.0 \mathrm{Ac} a$ & $1.0 \mathrm{Ab} a$ \\
\hline NS 6909 IPRO & $1.3 \mathrm{Ac} a$ & $2.0 \mathrm{Aa} b$ & $1.3 \mathrm{Ab} a$ & $1.3 \mathrm{Ac} a$ & $1.3 \mathrm{Ab} a$ \\
\hline NS 7670 RR & $2.3 \mathrm{Ab} b$ & $2.0 \mathrm{Aa} b$ & $2.0 \mathrm{Ab} b$ & $2.3 \mathrm{Ab} b$ & $2.1 \mathrm{Aa} b$ \\
\hline Produza IPRO & $3.0 \mathrm{Ba} b$ & $2.0 \mathrm{Ca} b$ & $3.0 \mathrm{Ba} b$ & $4.0 \mathrm{Aa} c$ & $2.3 \mathrm{Ca} b$ \\
\hline M 6410 IPRO & $1.5 \mathrm{Bc} a$ & $2.3 \mathrm{Aa} b$ & $1.5 \mathrm{Bb} a$ & $2.0 \mathrm{Ab} b$ & $1.3 \mathrm{Bb} a$ \\
\hline
\end{tabular}

* Uppercase letters refer to the comparison between treatments, within each location and cultivar (row); lowercase letters compare the cultivars within each treatment and location (column); and letters in italics compare the cultivars and treatments within each location (column). CV 1 (\%): 34.3 ; CV 2 (\%): 28 ; overall mean: 1.4. 
Table 3. Plant height $(\mathrm{cm})$ of soybean cultivars, according to the treatments lactofen, kinetin, cutting of apical buds and lactofen + kinetin.

\begin{tabular}{lccccc|c}
\hline Cultivars/treatments & Control & Lactofen + kinetin & Kinetin & Cutting & Lactofen & Mean \\
\hline M 5917 IPRO & $81.4 \mathrm{Ac} *$ & $79.5 \mathrm{Ac}$ & $78.8 \mathrm{Ac}$ & $59.1 \mathrm{Bc}$ & $76.0 \mathrm{Ac}$ & $75.0 \mathrm{C}$ \\
BMX Lança IPRO & $71.0 \mathrm{Ad}$ & $68.3 \mathrm{Ad}$ & $69.1 \mathrm{Ad}$ & $57.0 \mathrm{Bc}$ & $68.5 \mathrm{Ad}$ & $67.0 \mathrm{D}$ \\
NS 6909 IPRO & $91.8 \mathrm{Ab}$ & $89.8 \mathrm{Ab}$ & $88.0 \mathrm{Ab}$ & $67.3 \mathrm{Bb}$ & $84.6 \mathrm{Ab}$ & $84.3 \mathrm{~B}$ \\
NS 7670 RR & $95.6 \mathrm{Ab}$ & $96.6 \mathrm{Aa}$ & $94.3 \mathrm{Aa}$ & $74.4 \mathrm{Ba}$ & $95.3 \mathrm{Aa}$ & $91.2 \mathrm{~A}$ \\
Produza IPRO & $101.7 \mathrm{Aa}$ & $96.0 \mathrm{Aa}$ & $97.5 \mathrm{Aa}$ & $71.7 \mathrm{Ca}$ & $87.7 \mathrm{Bb}$ & $91.0 \mathrm{~A}$ \\
M 6410 IPRO & $92.6 \mathrm{Ab}$ & $88.8 \mathrm{Ab}$ & $86.4 \mathrm{Ab}$ & $72.5 \mathrm{Ba}$ & $87.4 \mathrm{Ab}$ & $86.0 \mathrm{~B}$ \\
\hline Mean & $89.0 \mathrm{~A}$ & $86.5 \mathrm{~B}$ & $85.7 \mathrm{~B}$ & $67.0 \mathrm{D}$ & $83.3 \mathrm{C}$ & - \\
\hline
\end{tabular}

* Uppercase letters compare treatments (row) and lowercase letters compare cultivars (column). CV 1 (\%): 7.0; CV 2 (\%): 8.7 ; overall mean: 82.3.

main stem. In contrast, about a week after spraying the lactofen treatments, injuries were observed in the terminal leaves and in the apical bud of the plants, caused by the accumulation of photodynamic compounds, such as protoporphyrins, damaging the photosynthetic and respiratory processes (Duke et al. 1991) and inducing an oxidative damage that leads to cell death (Larkin 2016). In the environmental conditions in which the experiments were carried out, mainly in the absence of water deficit, these injuries did not affect the growth of the plants. Furthermore, it is worth observing that there is not an agreement in the literature on the reduction in the height of soybean plants caused by the use of lactofen (Souza et al. 2002, Heiffig et al. 2006), because issues related to the production environment should be considered. Among them, water and temperature stresses, soon after the application of these herbicides, must be taken into acount.

For the variables number of nodes and number of branches per plant, there was no interaction among cultivars, cultivation sites and treatments. The cultivars presented statistical differences for the average number of total nodes per plant, with NS 7670 RR presenting the highest number (16), when compared to all the others (Figure 1a). In addition, M 5917 IPRO and Produza IPRO had the lowest number of lateral branches, if compared to the other factors, such as soil fertility, genetics, sowing density and climatic conditions, which interfere directly on plant growth and development, what may explain the difference between the numbers of nodes among the studied cultivars. The biggest number of nodes per plant in the cultivar NS 7670 RR may have occurred due to its longer cycle. The longer the vegetative stages, the longer is the period for the formation of plant structures.
In agreement with the results obtained in this study, Rosa et al. (2018) also observed no change in the number of nodes per plant for the cultivars NA 5909 RG and BMS Potency RR, depending on the application of lactofen. The definition of the number of nodes in the soybean crop occurs from the V4 stage, through several factors that are involved in this process, such as mineral nutrition and water stress, but mainly by hormonal factors, in which auxin and cytokinin are the two hormones responsible (Taiz \& Zeiger 2013). The treatments were applied at the moment when the plants were going through the definition of the number of nodes. However, the results show that the difference in the number of nodes among the cultivars occurred mainly due to factors that are not linked to the treatments with lactofen, because, as it can be seen in Figure $1 b$, the only treatment that differed for number of nodes was the cutting of apical buds.

On average, among all the cultivars, cutting the apical buds decreased in about five the total of nodes per plant, when compared to the other treatments (Figure 1b). This result was already expected, once the cut of apical buds forced the plant to stop growing, in terms of height, at the V6 vegetative stage, with only six developed nodes. On the other hand, plants with apical bud cut presented a greater number of lateral branches, if compared to the other treatments. The removal of the apical meristem causes a hormonal imbalance inside the plant, in which the concentration of cytokinin rises, as the concentration of auxin reduces, inducing the development of a greater number of lateral buds in the branches. In addition, the sowing density and soil fertility must be considered (Soares 2014, Gallon et al. 2016).

Increases in soybean yield are often related to an increase in the number of branches, due to the increase in the number of productive nodes. However, 

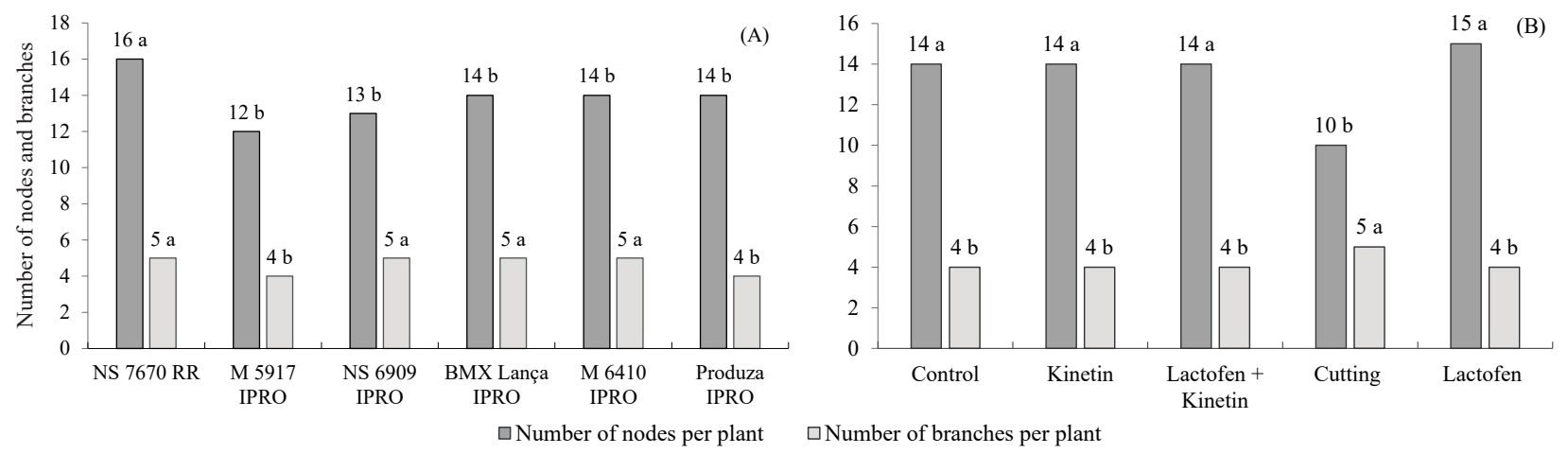

Figure 1. Number of nodes and number of branches per plant, depending on the cultivars (A) and treatments (B). Lactofen: $144 \mathrm{~g}$ ha ${ }^{1}$; lactofen + kinetin: 144 and $0.5 \mathrm{~g} \mathrm{ha}^{1}$; kinetin: $0.5 \mathrm{~g} \mathrm{ha}^{1}$; cutting of apical buds and control without product application. Scott-Knott test at $1 \%$ of probability.

it is necessary that, besides increasing the number of productive aspects, an increase in the "fruit setting" and "pods setting" occurs (Board \& Kahlon 2011, Egli 2013, Ohyama et al. 2013).

As for the number of pods and grains per plant, there were differences among the cultivars, but without a variation pattern (Table 4), as their behavior depended on the location. In average, the plants grown in Lavras presented a lower number of pods and grains per plant, when compared to those grown in Nazareno and Itutinga. This result may have happened due to the climatic and soil conditions of each environment. In Nazareno and Itutinga, the trials were conducted in areas where the no-tillage system has been used for many years. In addition, these regions have milder temperatures and higher precipitations, what may have influenced the higher production of pods and grains, once the flower abortion might have been lower, unlike in Lavras.

The number of pods per plant is a production component that contributes to increase the grain yield per plant and, consequently, the crop yield. However, despite the greater number of pods, it is also required the production of enough energy from the photosynthetic process to maintain the grain filling in the pods. The supply of a higher amount of light to soybean plants that are in the beginning of bloomimg enables a bigger amount of mature pods at the end of the cycle and, consequently, an increase in yield (Liu et al. 2012, Egli 2013, Ohyama et al. 2013).

The treatments, in general, had little influence on the increase of the mass of 100 grains, when

Table 4. Number of pods and number of grains per plant, according to the cultivars in each environment.

\begin{tabular}{|c|c|c|c|c|}
\hline \multirow{2}{*}{ Cultivars/locations } & \multicolumn{4}{|c|}{ - Number of pods per plant } \\
\hline & Nazareno & Lavras & Itutinga & Mean \\
\hline BMX Lança IPRO & $47.1 \mathrm{Bc}^{*}$ & $40.0 \mathrm{Bb}$ & $55.7 \mathrm{Ab}$ & $47.6 \mathrm{~B}$ \\
\hline NS 6909 IPRO & $56.8 \mathrm{Ab}$ & $42.7 \mathrm{Bb}$ & $49.8 \mathrm{Ab}$ & $49.8 \mathrm{~B}$ \\
\hline NS 7670 RR & $71.4 \mathrm{Aa}$ & $64.7 \mathrm{Aa}$ & $65.9 \mathrm{Aa}$ & $67.3 \mathrm{~A}$ \\
\hline Produza IPRO & $50.3 \mathrm{Ab}$ & $44.8 \mathrm{Ab}$ & $48.6 \mathrm{Ab}$ & $47.9 \mathrm{~B}$ \\
\hline M 6410 IPRO & $68.5 \mathrm{Aa}$ & $40.6 \mathrm{Cb}$ & $49.6 \mathrm{Bb}$ & $52.9 \mathrm{~B}$ \\
\hline Mean & $55.8 \mathrm{~A}$ & $45.2 \mathrm{~B}$ & $53.0 \mathrm{~A}$ & - \\
\hline \multirow{2}{*}{ Cultivars/locations } & \multicolumn{4}{|c|}{ Number of grains per plant } \\
\hline & Nazareno & Lavras & Itutinga & Mean \\
\hline BMX Lança IPRO & $112.6 \mathrm{Bc}$ & $91.1 \mathrm{Cb}$ & $135.0 \mathrm{Aa}$ & $113 \mathrm{~B}$ \\
\hline NS 6909 IPRO & $127.7 \mathrm{Ab}$ & $93.3 \mathrm{Bb}$ & $113.7 \mathrm{Aa}$ & $112 \mathrm{~B}$ \\
\hline NS 7670 RR & $141.4 \mathrm{Ab}$ & $129.5 \mathrm{Aa}$ & $135.5 \mathrm{Aa}$ & $136 \mathrm{~A}$ \\
\hline Produza IPRO & $128.6 \mathrm{Ab}$ & $111.3 \mathrm{Aa}$ & $129.1 \mathrm{Aa}$ & $123 \mathrm{~A}$ \\
\hline M 6410 IPRO & $173.4 \mathrm{Aa}$ & $99.0 \mathrm{Cb}$ & $126.7 \mathrm{Ba}$ & $133 \mathrm{~A}$ \\
\hline Mean & $130.1 \mathrm{~A}$ & $103.0 \mathrm{~B}$ & $126.6 \mathrm{~A}$ & - \\
\hline
\end{tabular}


compared to the control (Table 5), being in accordance with the results obtained by Gallon et al. (2016) and Rosa (2018), with application of lactofen in soybean plants. When comparing the cultivars, in general, M 5917 IPRO, NS 6909 IPRO and Produza IPRO were the ones that showed the highest values for mass of 100 grains. For the average of all the treatments and locations, Produza IPRO was the one with the highest mass of 100 grains, when compared to the others. These results corroborate the hypothesis that this variable is strongly related to genetic factors of the cultivars, and that the use of lactofen and phytohormone did not have a great influence. Phytotoxicity caused by herbicide affects only the new leaves of plants and, during the grain filling, the redistribution of carbohydrates, minerals and nitrogen compounds occurs from the leaves in senescence; thus, the application of lactofen does not interfere in the accumulation of dry matter and nutrients in the grains (Mundstock \& Thomas 2005).

For the yield assessment, the effect of treatments was variable with the production location (Table 6). In Nazareno, the plants subjected to the treatments cutting of the apical buds, lactofen and lactofen + kinetin were the ones that presented the highest average yields. On the other hand, in Lavras, the highest yields were obtained after the application of the treatments kinetin, lactofen + kinetin and cutting of the apical buds. In Itutinga, the plants subjected to the cut of apical buds and the application of lactofen presented the highest yields.

On the average of all locations, there were no responses to the application of kinetin, what possibly occurred due to the applied dose $\left(50 \mathrm{mg} \mathrm{ha}^{-1}\right)$. Passos et al. (2011) obtained average increases of $22.5 \%$ $\left(718 \mathrm{~kg} \mathrm{ha}^{-1}\right)$ and $32.3 \%\left(1,030 \mathrm{~kg} \mathrm{ha}^{-1}\right)$, in relation to the control, applying $250 \mathrm{mg} \mathrm{ha}^{-1}$ and $1,000 \mathrm{mg} \mathrm{ha}^{-1}$ of kinetin in R3, respectively. According to the authors, this result may have occurred due to the accumulation of dry mass, in the vegetative parts that occur between R3 and R5, increasing the 1,000-seed weight after the application of the phytohormone, and consequently leading the crop yield to be higher as well (Carlson et al. 1987, Ritchie et al. 1997).

It is worth mentioning that, on the average of all locations, the plants that received application of lactofen and those with cut in the apical buds presented the highest yields, when compared to the others. Similarly to what was observed in this study, Rosa (2018) and Soares (2014) noticed higher grain yields per hectare after the application of lactofen in doses of $140 \mathrm{~g} \mathrm{ha}^{-1}$ and $240 \mathrm{~g} \mathrm{ha}^{-1}$, in different soybean cultivars. On the other hand, Gallon et al. (2016) did not increase the yield when applying lactofen (144 $\left.\mathrm{g} \mathrm{ha}^{-1}\right)$ at the V7 stage, for the cultivar CD 214 RR, since, apparently, there was not enough

Table 5. Mass of 100 grains (g) of soybean cultivars, according to the application of the treatments lactofen, kinetin, cutting of apical buds and lactofen + kinetin.

\begin{tabular}{llcccc:c}
\hline \multicolumn{1}{c}{ Cultivars/treatments } & Control & Lactofen + kinetin & Kinetin & Cutting & Lactofen & Mean \\
\hline BMX Lança IPRO & $17.7 \mathrm{Bc}$ & $18.0 \mathrm{Bb}$ & $18.0 \mathrm{Bc}$ & $19.6 \mathrm{Ab}$ & $18.4 \mathrm{Bc}$ & $18.3 \mathrm{C}$ \\
NS 6909 IPRO & $19.5 \mathrm{Ab}$ & $19.8 \mathrm{Aa}$ & $20.5 \mathrm{Ab}$ & $20.8 \mathrm{Aa}$ & $19.7 \mathrm{Ab}$ & $20.1 \mathrm{~B}$ \\
NS 7670 RR & $17.5 \mathrm{Ac}$ & $17.7 \mathrm{Ab}$ & $17.9 \mathrm{Ac}$ & $17.8 \mathrm{Ac}$ & $16.6 \mathrm{Ad}$ & $17.5 \mathrm{D}$ \\
Produza IPRO & $21.1 \mathrm{Aa}$ & $20.3 \mathrm{Aa}$ & $21.9 \mathrm{Aa}$ & $20.7 \mathrm{Aa}$ & $20.9 \mathrm{Aa}$ & $21.0 \mathrm{~A}$ \\
M 6410 IPRO & $15.9 \mathrm{Ad}$ & $15.0 \mathrm{Ac}$ & $15.1 \mathrm{Ad}$ & $15.6 \mathrm{Ad}$ & $15.8 \mathrm{Ad}$ & $15.5 \mathrm{E}$ \\
\hline Mean & $18.4 \mathrm{~B}$ & $18.4 \mathrm{~B}$ & $18.9 \mathrm{~A}$ & $19.1 \mathrm{~A}$ & $18.5 \mathrm{~B}$ & - \\
\hline
\end{tabular}

* Uppercase letters refer to the comparison among treatments (row) and lowercase letters compare cultivars (column). CV 1 (\%): 7.0 ; CV 2 (\%): 8.7; overall mean: 18.64.

Table 6. Grain yield $\left(\mathrm{kg} \mathrm{ha}^{-1}\right)$, according to the treatments in each location.

\begin{tabular}{llllc}
\hline \multicolumn{1}{c}{ Treatments/location } & Nazareno & Lavras & Itutinga & Mean \\
\hline Control & $3.668 \mathrm{Ab}^{*}$ & $3.315 \mathrm{Ab}$ & $3.529 \mathrm{Ab}$ & $3.504 \mathrm{~B}$ \\
Lactofen + kinetin & $4.036 \mathrm{Aa}$ & $3.754 \mathrm{Aa}$ & $3.199 \mathrm{Bb}$ & $3.663 \mathrm{~B}$ \\
Kinetin & $3.879 \mathrm{Ab}$ & $3.787 \mathrm{Aa}$ & $3.352 \mathrm{Bb}$ & $3.739 \mathrm{~B}$ \\
Cutting & $4.249 \mathrm{Aa}$ & $3.702 \mathrm{Ba}$ & $3.779 \mathrm{Ba}$ & $3.910 \mathrm{~A}$ \\
Lactofen & $4.145 \mathrm{Aa}$ & $3.516 \mathrm{Bb}$ & $3.790 \mathrm{Ba}$ & $3.817 \mathrm{~A}$ \\
\hline Mean & $3.995 \mathrm{~A}$ & $3.614 \mathrm{~B}$ & $3.530 \mathrm{~B}$ & - \\
\hline
\end{tabular}

*Uppercase letters refer to the comparison among locations (row) and lowercase letters compare the treatments (column). CV 1 (\%): 20 ; CV 2 (\%):17.7; overall mean: 3.713. 
time for the plant to recover from the damage caused by the phytotoxicity of the herbicide.

The average increase of $312 \mathrm{~kg} \mathrm{ha}^{-1}$ of soybean with the application of lactofen must be seen in a positive way, since it is a low-cost product, when compared to synthetic growth regulators. However, as the application of lactofen causes phytotoxicity in soybean, it is extremely important that it does not suffer any other kind of stress, such as water deficit, after being sprayed with the product. The recovery of the canopy through the growth of new leaves that did not have contact with the herbicide takes around 20 days, under normal conditions (Rosa 2018).

The potential yield of soybean crops depend on factors such as the capacity to set fruits into mature pods, what may be influenced by a low supply of carbohydrates at the beginning of the soybean reproductive stage (R1) (Silva et al. 2018). In the present study, there was no drastic reduction in the availability of carbohydrates for the fixation of reproductive organs, since all the treatments, when compared to the control, obtained a greater yield (Table 6). The results agree with Fageria et al. (2006), who pointed out that the soybean yield is limited by the capacity of the source to synthesize assimilates at the beginning of the reproductive stage.

When quantifying the carbohydrates of the three studied cultivars (BMX Lança IPRO, NS 7670 RR and MS 5917 IPRO), it can be observed that, in general, the greatest alterations occurred in the treatments with the herbicide, mainly changing the amount of sucrose and total sugars on the leaves, when compared to the control treatment (Table 7).

When the interaction between the herbicide lactofen + kinetin occurred (Table 7), the sucrose, which is the main photosynthetic product exported from the soybean leaf, had its concentration strongly reduced. The reduction in the sucrose content in the leaves might be related to damages in the photosynthetic apparatus and also the reduction of the leaf area after the plant undergoes the stress caused by the action of the herbicide. However, as the same response pattern was observed when analyzing the reducing sugars resulting from the sucrose hydrolysis, it is possible that there was a greater oxidation of these sugars, in order to supply carbon skeletons and energy compounds for the production of new tissues (Stein \& Granot 2019).

The application of the treatments resulted in accumulation of starch in the soybean leaves, except for those with the application of lactofen (Table 7). The accumulation of starch in the tissues occurs when the production of photoassimilates is higher than the demand. Starch is a polysaccharide used as an energy supply and its hydrolysis provides substrate in the form of glucose for the biosynthesis of sucrose in the cytosol (Schleucher et al. 1998). Overall, it can be observed that, at the beginning of the reproductive

Table 7. Contents of sucrose, starch, reducing and total sugars ( $\mu \mathrm{mol}$ of glucose $\mathrm{g}^{-1}$ of dry matter), for the cultivars NS 7670 RR, MS 5917 IPRO and BMX Launches IPRO, according to the treatments.

\begin{tabular}{|c|c|c|c|c|c|c|}
\hline \multirow{2}{*}{ Treatments/sugars } & \multicolumn{3}{|c|}{ - Sucrose } & \multicolumn{3}{|c|}{ Starch } \\
\hline & Leaf & Branch & Root & Leaf & Branch & Root \\
\hline Kinetin & $152.82 \mathrm{c}^{*}$ & $91.44 \mathrm{~b}$ & $100.09 \mathrm{a}$ & $32.61 \mathrm{a}$ & $10.87 \mathrm{c}$ & $13.67 \mathrm{a}$ \\
\hline Cutting & $190.39 \mathrm{~b}$ & $107.63 \mathrm{a}$ & $106.63 \mathrm{a}$ & $33.44 \mathrm{a}$ & $12.28 \mathrm{c}$ & $13.66 \mathrm{a}$ \\
\hline Lactofen + kinetin & $133.81 \mathrm{c}$ & $86.85 \mathrm{~b}$ & $91.58 \mathrm{a}$ & $29.87 \mathrm{a}$ & $15.44 \mathrm{~b}$ & $11.72 \mathrm{a}$ \\
\hline Control & $233.21 \mathrm{a}$ & $80.91 \mathrm{~b}$ & $77.81 \mathrm{a}$ & $20.71 b$ & $18.45 \mathrm{a}$ & $15.52 \mathrm{a}$ \\
\hline Lactofen & $200.16 \mathrm{~b}$ & $68.15 \mathrm{c}$ & $75.03 \mathrm{a}$ & $21.17 \mathrm{~b}$ & $10.79 \mathrm{c}$ & $13.37 \mathrm{a}$ \\
\hline CV $(\%)$ & 14.91 & 9.16 & 29.74 & 22.86 & 11.66 & 30.39 \\
\hline Mean & 182.08 & 87.00 & 90.23 & 27.56 & 13.56 & 13.58 \\
\hline \multirow{2}{*}{ Treatments/sugars } & \multicolumn{3}{|c|}{ Reducing sugars } & \multicolumn{3}{|c|}{ - Total sugars } \\
\hline & Leaf & Branch & Root & Leaf & Branch & Root \\
\hline Kinetin & $135.29 \mathrm{~b}$ & $73.94 \mathrm{a}$ & $31.22 \mathrm{a}$ & $288.11 \mathrm{c}$ & $165.38 \mathrm{a}$ & $131.32 \mathrm{a}$ \\
\hline Cutting & $196.02 \mathrm{~b}$ & $51.39 \mathrm{~b}$ & $48.50 \mathrm{a}$ & $386.41 \mathrm{~b}$ & $159.03 \mathrm{a}$ & $155.13 \mathrm{a}$ \\
\hline Lactofen + kinetin & $103.11 \mathrm{c}$ & $57.50 \mathrm{~b}$ & $20.13 \mathrm{a}$ & $236.92 \mathrm{~d}$ & $144.36 \mathrm{~b}$ & $111.71 \mathrm{a}$ \\
\hline Control & $241.66 \mathrm{a}$ & $84.81 \mathrm{a}$ & $32.35 \mathrm{a}$ & $474.88 \mathrm{a}$ & $165.72 \mathrm{a}$ & $110.17 \mathrm{a}$ \\
\hline Lactofen & $117.24 \mathrm{c}$ & $58.89 \mathrm{~b}$ & $30.78 \mathrm{a}$ & $317.40 \mathrm{c}$ & $127.05 \mathrm{~b}$ & $105.82 \mathrm{a}$ \\
\hline CV $(\%)$ & 20.82 & 27.02 & 53.12 & 16.00 & 14.12 & 33.55 \\
\hline Mean & 158.66 & 65.31 & 32.60 & 340.74 & 152.31 & 122.83 \\
\hline
\end{tabular}

* Lowercase letters compare the treatments in each part of the studied plant (column). 
stage, there were no changes in the carbohydrate balance for the root system. This result may have occurred mainly due to the fact that carbohydrates are stored in leaves, stems and branches during the growing season. When the reproductive stage starts, these compounds are translocated to the reproductive structures in development and later to filling the grains (source versus demand ratio).

\section{CONCLUSIONS}

1. The morpho-agronomic traits were modified after the application of lactofen in V6, for the studied cultivars;

2. The application of the phytohormone kinetin did not change the morpho-agronomic traits and yield of the studied cultivars;

3. The application of lactofen resulted in an average increase of $312 \mathrm{~kg} \mathrm{ha}^{-1}$ of soybean grains;

4. The treatments did not induce changes in the partitioning of carbohydrates destined to the roots.

\section{REFERENCES}

BERNARD, R. L.; CHAMBERLAIN, D. W.; LAWRENCE, R. D. Results of the cooperative uniform soybean tests. Washington, DC: USDA, 1965.

BOARD, J. E.; KAHLON, C. S. Soybean yield formation: what controls it and how it can be improved. In: ELSHAMY, H. A. Soybean physiology and biochemistry. Rijeka: IntechOpen, 2011. p. 1-36.

CARLSON, D. R.; DYER, D. J.; COTTERMAN, C. D.; DURLEY, R. C. The physiological basis for cytokinin induced increases in pod set in IX93-100 soybeans. Plant Physiology, v. 84, n. 2, p. 233-239, 1987.

DUKE, S. O.; LYDON, J.; BECERRIL, J. M.; SHERMAN, T. D.; LEHNEM JUNIOR, L. P.; MATSUMOTO, H. Protoporphyrinogen oxidase-inhibiting herbicides. Weed Science, v. 39, n. 3, p. 465-473, 1991.

EGLI, D. The relationship between the number of nodes and pods in soybean communities. Crop Science, v. 53, n. 4, p. 1668-1676, 2013.

EMPRESA BRASILEIRA DE PESQUISA AGROPECUÁRIA (Embrapa). Centro Nacional de Pesquisa de Solos. Sistema brasileiro de classificação de solos. Rio de Janeiro: Embrapa, 2013.

FAGERIA, N. K.; BALIGAR, V. C.; CLARK, R. Physiology of crop production. New York: Haworth, 2006.
FEHR, W. R.; CAVINESS, C. E. Stages of soybean development. Ames: Iowa State University of Science and Technology, 1977.

FERREIRA, D. F. Sisvar: um sistema computacional de análise estatística. Ciência e Agrotecnologia, v. 35, n. 6, p. 1039-1042, 2011.

GALLON, M.; BUZZELLO, G. L.; TREZZI, M. M.; DIESEL, F.; SILVA, H. L. Ação de herbicidas inibidores da PROTOX sobre o desenvolvimento, acamamento e produtividade da soja. Revista Brasileira de Herbicidas, v. 15, n. 3, p. 232-240, 2016.

HEIFFIG, L. S.; CÂMARA, G. M. D. S.; MARQUES, L. A.; PEDROSO, D. B.; PIEDADE, S. M. D. S. Fechamento e índice de área foliar na cultura da soja em diferentes arranjos espaciais. Bragantia, v. 65, n. 2, p. 285-295, 2006.

LARKIN, R. M. Tetrapyrrole signaling in plants. Frontiers in Plant Science, v. 7, e1586, 2016.

LIU, B.; LIU, X. B.; WANG, C.; JIN, J.; HERBERT, S. J.; HASHEMI, M. Responses of soybean yield and yield components to light enrichment and planting density. International Journal of Plant Production, v. 4, n. 1, p. 1-9, 2012.

MILLER, G. L. Use of dinitrosalicylic acid reagent for determination of reducing sugar. Analytical Chemistry, v. 31, n. 3, p. 426-428, 1959.

MORAES, F. A. Doses de calcário na construção da fertilidade do perfil do solo. Dissertação (Mestrado em Fitotecnia) - Universidade Federal de Lavras, Lavras, 2019.

MÜLLER, D.; LEYSER, O. Auxin, cytokinin and the control of shoot branching. Annals of Botany, v. 107, n. 7, p. 1203-1212, 2011.

MUNDSTOCK, C. M.; THOMAS, A. L. Fatores que afetam o crescimento e o rendimento de grãos. Porto Alegre: Ed. UFRGS, 2005.

OHYAMA, T.; MINAGAWA, R.; ISHIKAWA, S.; YAMAMOTO, M.; HUNG, N. V. P.; OHTAKE, N.; TAKAHASHI, Y. Soybean seed production and nitrogen nutrition. Rijeka: InTech, 2013.

PASSOS, A. M. A.; REZENDE, P. M. D.; CARVALHO, E. D. A.; SAVELI, R. A. M. Cinetina e nitrato de potássio em características agronômicas de soja. Pesquisa Agropecuária Brasileira, v. 43, n. 7, p. 925-928, 2011.

RITCHIE, S. W.; HANWAY, J. J.; THOMPSON, H. E. How a soybean plant develops. Ames: Iowa State University of Science and Technology, 1997.

ROSA, W. P. Eficiência produtiva e deposição de produtos fitossanitários em cultivares de soja submetidas 
à aplicação de lactofen. Dissertação (Mestrado em Agronomia) - Faculdade de Agronomia e Medicina Veterinária de Passo Fundo, Passo Fundo, 2018.

SCHLEUCHER, J.; VANDERVEER, P. J.; SHARKEY, T. D. Export of carbon from chloroplasts at night. Plant Physiology, v. 118, n. 4, p. 1439- 1445, 1998.

SHEKOOFA, A.; EMAM, Y. Effects of nitrogen fertilization and plant growth regulators (PGRs) on yield of wheat (Triticum aestivum L.) cv. Shiraz. Journal of Agricultural Science and Technology, v. 10, n. 2, p. 101108, 2008.

SILVA, A. J. D.; MAGALHÃES FILHO, J. R.; SALES, C. R. G.; PIRES, R. C. D. M.; MACHADO, E. C. Source-sink relationships in two soybean cultivars with indeterminate growth under water deficit. Bragantia, v. 77, n. 1, p. 2335, 2018.

SILVA, F. C. Manual de análises químicas de solos, plantas e fertilizantes. Rio de Janeiro: Embrapa Solos, 2009.

SMITH, M. R.; RAO, I. M.; MERCHANT, A. Source-sink relationships in crop plants and their influence on yield development and nutritional quality. Frontiers in Plant Science, v. 9, e1889, 2018.

SOARES, L. H. Manejo fisiológico com base em tratamento de sementes e aplicação de organominerais via foliar para sistemas de alto potencial produtivo de soja. 2014. Dissertação (Mestrado em Agronomia) - Escola Superior de Agricultura Luiz de Queiroz, Piracicaba, 2014.
SOUSA, D. M. G.; LOBATO, E. Correção do solo e adubação da cultura da soja. Planaltina, DF: Embrapa Cerrados, 1996.

SOUZA, C. A.; FIGUEIREDO, B. P.; COELHO, C. M. M.; CASA, R. T.; SANGOI, L. Arquitetura de plantas e produtividade da soja decorrente do uso de redutores de crescimento. Bioscience Journal, v. 29, n. 3, p. 634-643, 2013.

SOUZA, R. T.; CONSTANTIN, J.; VELENI, E. D.; MONTORIO, G. A.; MACIEL, C. D. D. G. Seletividade de combinações de herbicidas latifolicidas com lactofen para a cultura da soja. Scientia Agricola, v. 59, n. 1, p. 99106, 2002.

STEIN, O.; GRANOT, D. An overview of sucrose synthases in plants. Frontiers in Plant Science, v. 10, e95, 2019.

TAIZ, L.; ZEIGER, E. Fisiologia vegetal. 3. ed. Porto Alegre: Artmed, 2013.

VITORINO, H. S.; MARTINS, D. Efeito do déficit hídrico na eficiência de herbicidas e nas características bioquímicas de Ipomoea grandifolia. Planta Daninha, v. 30, n. 1, p. 185-191, 2012.

YEMM, E. W.; WILLIS, A. J. The estimation of carbohydrates in plants extracts by antrone. Biochemical Journal, v. 57, n. 3, p. 508-514, 1954.

ZANANDREA, L.; ALVES, J. D.; DEUNER, S.; GOULART, F. P.; HENRIQUE, P. D. C.; SILVEIRA, N. M. Tolerance of Sesbania virgata plants to flooding. Australian Journal of Botany, v. 57, n. 8, p. 661-669, 2010. 